\title{
LOGIC GATE BASED AUTOMATIC WATER LEVEL CONTROLLER
}

\author{
Md. Moyeed Abrar ${ }^{1}$, Rajendra.R.Patil ${ }^{2}$ \\ ${ }^{I}$ M-Tech Scholar, Department of Electronics and Communication Engineering, Appa Institute of Engineering and \\ Technology, Gulbarga, Karnataka, India \\ ${ }^{2}$ Assistant Professor, Department of Electronics and Communication Engineering, Appa Institute of Engineering and \\ Technology, Gulbarga, Karnataka, India
}

\begin{abstract}
A range of level control systems and methods are used in Industries. Systems may be based on the use of floats, probes or sensors. Level control is one of continuous process that can be treated as an integrating process. The level controller can be applying on temperature control, pressure control and water control etc. The level controller is used with electrical probes or sensors. The ele ctrical probes are used with power supply and motor. The main objective of this paper is to design and develop an automatic water level controller to maintain the outlet process of the water level at its desired level. The paper also focuses on the need of the people to install automatic water level controller to avoid wastage of water.
\end{abstract}

Keywords: Automatic water level controller, Electrical probes or sensors, Level control, Power supply, motor.

\section{INTRODUCTION}

Water scarcity is a major problem that is gripping the major metro cities of the World; the main culprit is not availability but undue wastage. Most of the people who have easy access to resources like water have careless attitude toward this kind of issues but people who face this problem knows the worth of clean drinkable water and water for routine usage. The barrier on wastage not only gives us more financial savings, it also helps the environment and water cycle which in turn ensures that we save water for our future.

The solution to this problem is to use an automatic water level controller to avoid the water overflow and wastage. The automatic water level controllers are highly recommended for metro cities or areas where water is supplied through pipelines which are further distributed in homes, hotels, society's etc. Now days it is becoming necessary for big and small houses, bungalows, corporate, hospitals and multi storey buildings, especially in metro cities and big towns where there is no fixed time for water supply. In this regard the automatic water level controller reduces the wastage of water by cutting down any further overflow than what is needed.

The automatic water level controller designed here is on the basis of electro mechanical system using the digital technology [1], [2].The level controller can be used with electrical probes or sensors. Here, the electrical probes are used along with power supply and motor. The probes will be inserted inside the tank and motor will pump as the water goes down. The probes will detect the level of water and ON/OFF the motor. The level controller used here is the water sensor which will sense the low and high level of water in the water tank. If the water is low, the motor will pump the water and after the high level is reached it will stop to pump water [2], [7].

The rest of the paper is organized as follows: section 2 describes the proposed system. The section 3 focuses on the system design. The section 4 includes the features of automatic water level controller. The section 5 illustrates the advantages and disadvantages of the automatic water level controller. The survey of the work is reported in section 6 . The section 7 includes the scope for future work. Finally section 8 summarizes the paper and presents the concluding remark.

\section{PROPOSED SYSTEM}

\subsection{Problem Statement}

Today most of the water tank users have replaced conventional pumps with electrical pumps. But they find it very inconvenient for the condition of water pump because there is no effective water level indication system. As a result, if the mechanical sensor fails, there is a plenty of water wastage as well as wastage of power consumed by the motor pump. So the solution to this problem is to use an automatic water level controller using water sensor.

\subsection{Architecture Overview}

The block diagram of the automatic water level controller is shown in fig.1. The operation is based on the low voltage AC single sensing of levels. Water sensor is the level control sensor that senses the rise and fall of water and actuates the system. The three main units of the system are the overhead water tank, the pump and the sump. The Pump used in the system is a submersible pump. 


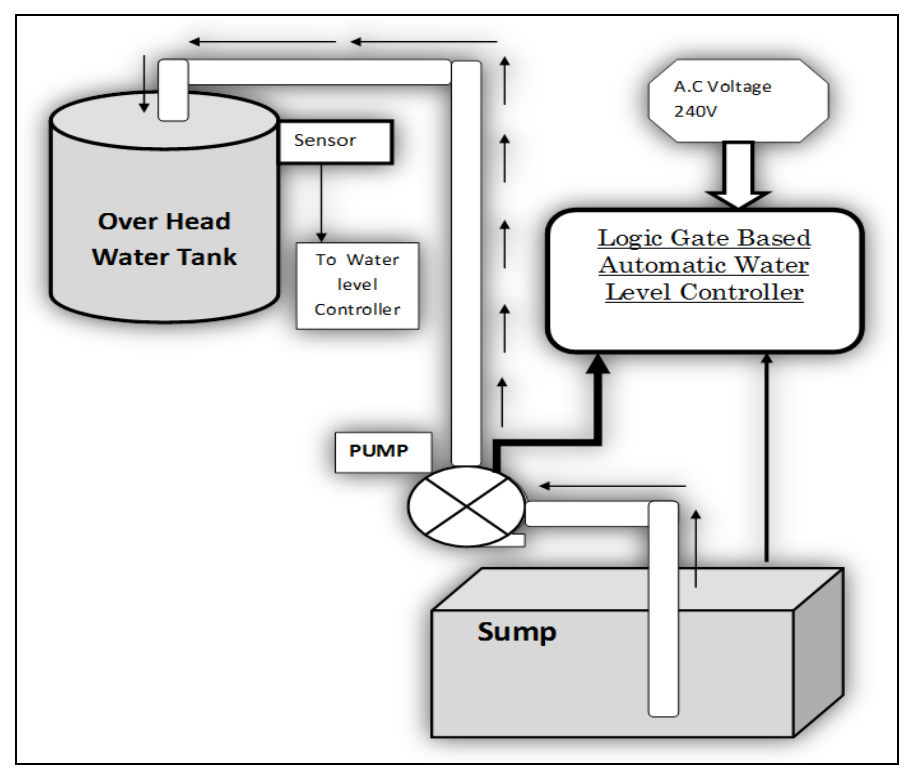

Fig 1 Functional block diagram of automatic water level controller.

\subsection{Circuit Schematic of Automatic Water Level}

\section{Controller}

The Circuit schematic of the proposed system is shown in fig.2.

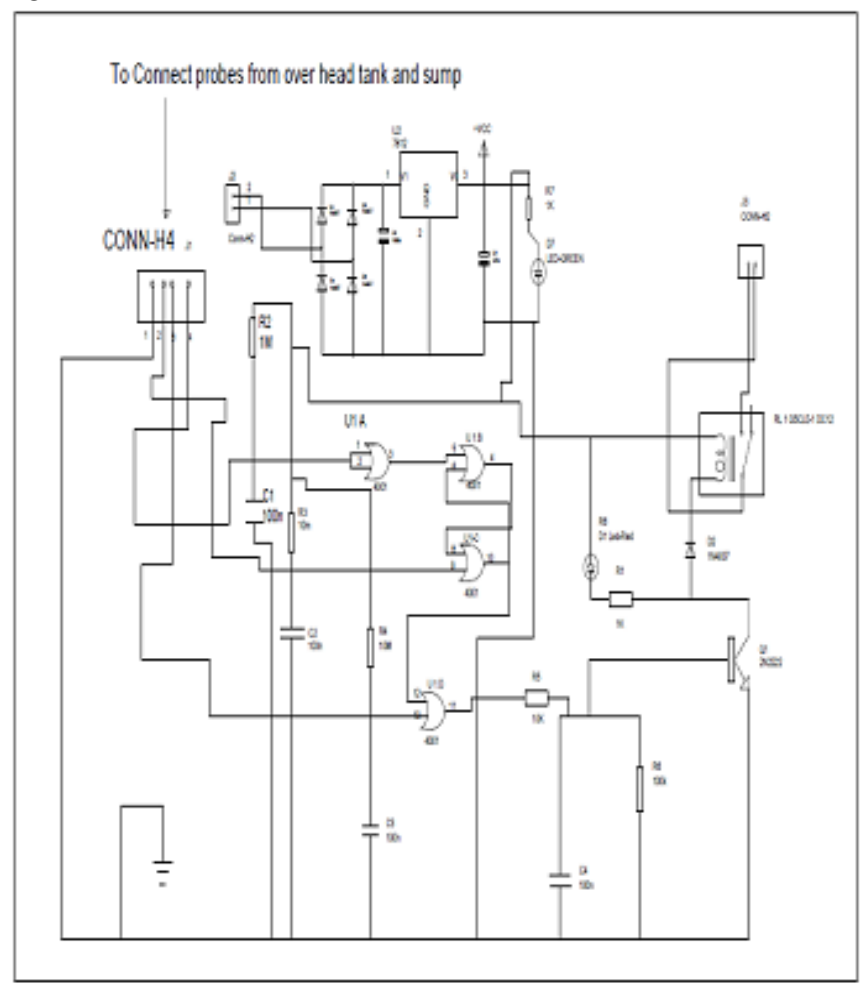

Fig.2 Circuit schematic of Proposed system

\subsection{Working of the Automatic Water Level}

\section{Controller}

The automatic pump controller minimizes the need for any manual switching of water pumps installed for the functionality of pumping water from a reservoir to an overhead tank. It instantly switches "ON" the pump once the water level within the tank falls below a specific low level (L), provided the water level in the reservoir is above a specific level (R). Subsequently, because the water level in the tank increases to an upper level (M), the pump is turned "OFF" instantly. The pump is turned "ON" only if the water level once again falls beneath level L in the tank, provided the level inside the reservoir is above R. This automated action continues. This is shown in fig. 3 .

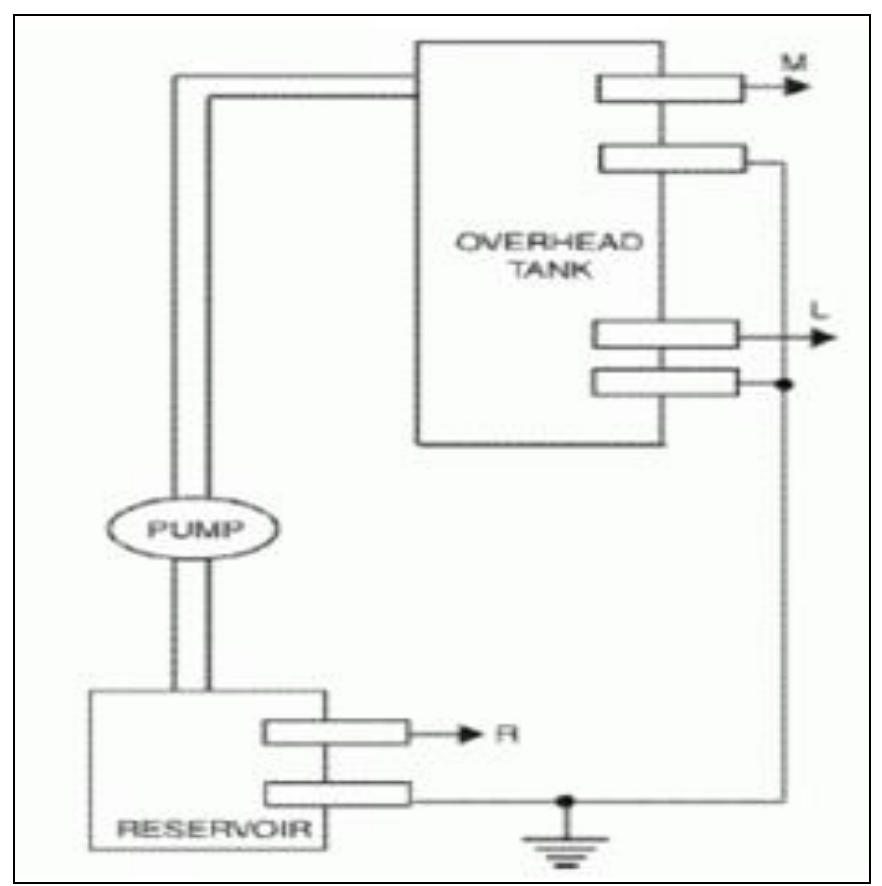

Fig 3 working diagram of automating water level controller

The circuit is intended to "overlook" the transient oscillations of the water level that would otherwise trigger the logic to modify its state rapidly and unnecessarily. The circuit works by using a single Complementary metal oxide semiconductor (CMOS) chip (CD4001) for logic processing. [8]

No utilization of any moving electromechanical elements within the water-level sensor has been made. This assures fast reaction, no wear and tear and no mechanical problems. The circuit diagram is seen on above image. The unit performed satisfactorily on a test run in conjunction with a $0.5 \mathrm{HP}$ motor and pump. In this system, we are using submersible pump.

The sensors applied to the circuit could be any two conducting probes, preferably resistant to electrolytic corrosion. For 
example, in the easiest case, an appropriately sealed audio jack could be utilized to operate as the sensor.

The circuit may also be utilized like a constant fluid level maintainer. For this objective, the probes $\mathrm{M}$ and $\mathrm{L}$ are brought pretty near to one another to make sure that the fluid level is maintained within the $\mathrm{M}$ and $\mathrm{L}$ levels.

The benefit of the system is that it could be applied to tanks, reservoirs of any volume whatsoever. Even so, the circuit cannot be applied for purely non conducting fluids. For nonconducting fluids, some modifications have to be prepared in the fluid level sensors. The circuit on the other hand can be kept intact. The photographic view of the proposed system is shown in fig. 4 .

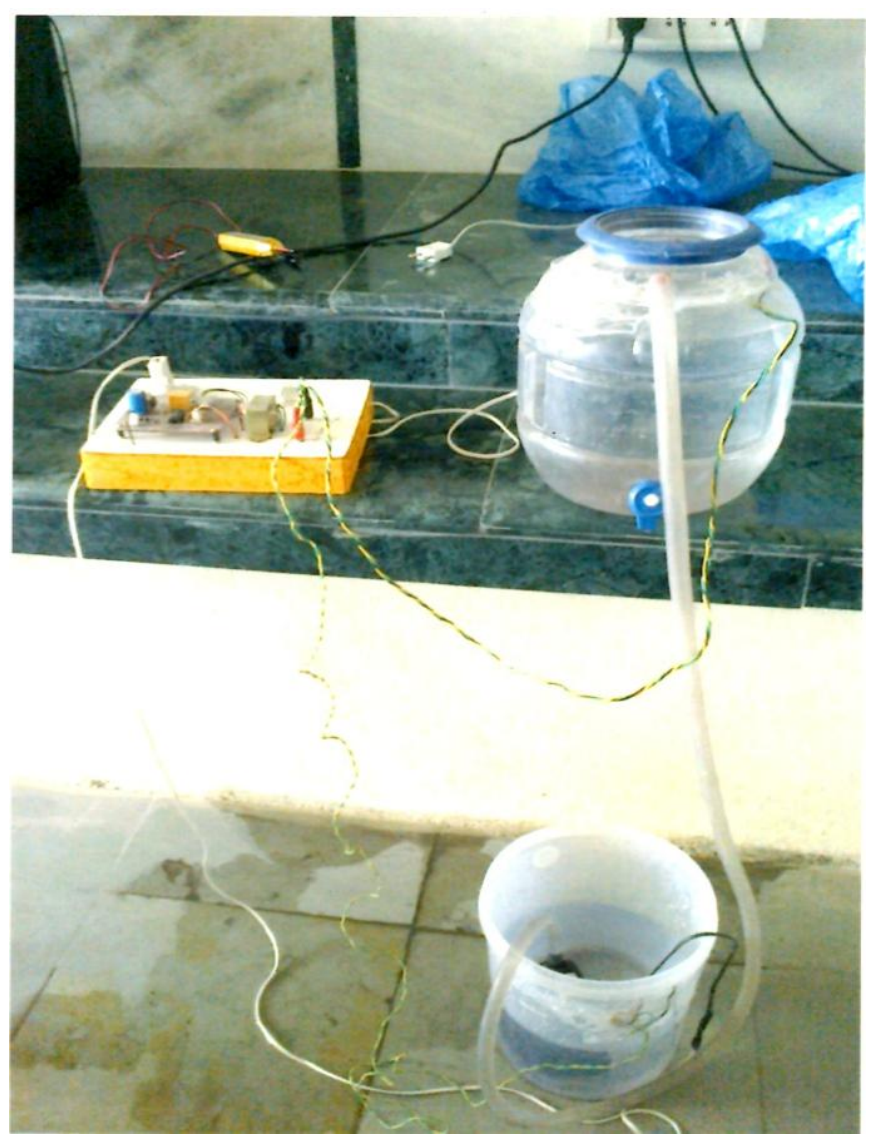

Fig 4 photographic view of the proposed system..

\section{DESIGN OF AUTOMATIC WATER LEVEL CONTROLLER}

The design of the automatic water level controller is carried out by assigning the logic levels for the over head tank, sump and the Pump set.

\subsection{Logic Level Definitions from Sensors}

For sump and overhead tank:

Logic-1 = water not present.

Logic $-0=$ water present.

For pump set:

Logic-1= pump set "ON".

Logic- $0=$ pump set "OFF".

The table 1 illustrates the logic assumed above and gives the expression for the system design.

Table 1 Truth table for the system design

\begin{tabular}{|c|c|c|c|}
\hline \multicolumn{3}{|l|}{ INPUT } & \multirow{3}{*}{$\begin{array}{l}\text { OUTPUT(Y } \\
\text { PUMP } \\
\text { STATUS }\end{array}$} \\
\hline \multicolumn{2}{|l|}{ O.H TANK } & \multirow{2}{*}{$\begin{array}{l}\text { SUMP } \\
\text { LOWER } \\
\text { LEVEL } \\
\text { (C) }\end{array}$} & \\
\hline $\begin{array}{l}\text { UPPER } \\
\text { LEVEL(A) }\end{array}$ & $\begin{array}{l}\text { LOWER } \\
\text { LEVEL } \\
\text { (B) }\end{array}$ & & \\
\hline $\mathbf{0}$ & $\overline{\mathbf{0}}$ & $\overline{\mathbf{0}}$ & $\mathbf{0}$ \\
\hline $\mathbf{0}$ & $\mathbf{0}$ & 1 & $\mathbf{0}$ \\
\hline $\mathbf{0}$ & 1 & $\mathbf{0}$ & $\mathbf{X}$ \\
\hline 0 & 1 & 1 & $\overline{\mathbf{0}}$ \\
\hline 1 & $\mathbf{0}$ & $\mathbf{0}$ & $\mathbf{0}$ \\
\hline 1 & $\mathbf{0}$ & 1 & $\overline{\mathbf{0}}$ \\
\hline 1 & 1 & O & 1 \\
\hline 1 & 1 & 1 & $\mathbf{0}$ \\
\hline
\end{tabular}

The expression for the system design is obtained above truth table as

$$
\mathrm{Y}=(\mathrm{A} \cdot \mathrm{B}) \cdot \overline{\mathrm{C}}
$$

Realizing the above expression with universal NOR gate

$$
\begin{aligned}
& \overline{\overline{\mathrm{Y}}}=\overline{\overline{(A \cdot B) \cdot \overline{\mathrm{C}}}} \\
& \mathrm{Y}=\overline{(\overline{\mathrm{A} \cdot \mathrm{B}})+\overline{\mathrm{C}}}
\end{aligned}
$$


From De-Morgan's theorem,

$$
\overline{(A . B)}=\bar{A}+\bar{B}
$$

Applying De-Morgan's theorem from equation (4) to equation (3), we get

$$
Y=\overline{(\overline{\mathrm{A}}+\overline{\mathrm{B}})+\mathrm{C}}
$$

Since

$$
\overline{\bar{C}}=C
$$

\section{FEATURES OF AUTOMATIC WATER LEVEL CONTROLLER}

$>$ Automatic water level controller will automatically start the pump set as the water level falls below predetermined level (usually $1 / 2$ tank) and shall switch off the pump set as soon as tank is full or water level in the lower tank is at below the minimum level.

$>$ Automatic water level controller provides the flexibility to decide about the water levels for operations of pump sets in upper/lower tanks.

$>$ Automatic water level controller gives the water flow indication as well as the voltage level indication.

> Automatic water level controller ensures no overflow or dry running of pump thereby saves electricity and water.

> Automatic water level controller can be treated as auto/manual operation switch for special operations like watering the plants from pump set.

> Automatic water level controller consumes little energy and ideal for continuous operation.

> Automatic water level controller have low ac voltage sensing circuit to avoid polarization of electrodes in water (long live sensors requires very rare cleaning of electrode ends) provided with special stainless steel and conducting electrodes.

> Automatic water level controller has built in indications for showing four levels in upper tank and three levels in lower tank.

\section{ADVANTAGES AND DISADVANTAGES OF}

\section{AUTOMATIC WATER LEVEL CONTROLLER}

\subsection{Advantages}

$>$ Automatic water level controller is used to automatically fill the overhead tank as and when it gets empty and monitor the water level in it.

$>$ Automatic water level controller is simple and easy to install.
$>$ Automatic water level controller has low maintenance.

$>$ Automatic water level controller has compact and elegant design.

$>$ Automatic water level controller is fully automatic.

$>$ Automatic water level controller with its precise working saves water and the motor energy.

$>$ Automatic water level controller avoids the seepage of walls and roofs when the tank overflows.

$>$ Automatic water level controller is efficient in operation and enhances the pump set life.

$>$ Automatic water level controller is ideal as it is difficult to access overhead tanks.

$>$ Automatic water level controller has safe operation of motor/pump within permissible voltage limits.

\subsection{Disadvantages}

$>$ It is a passive electrical system and hence it requires continuous power supply.

\section{SURVEY OF THE WORK}

The water level controller has gained wide attention in recent years in India and the rest of the World. The survey of the work was carried out in accordance with views of people of Gulbarga district whether they have automatic water level controller installed in their homes and if not, whether they would like to install automatic water level controllers in their homes. The response of the people to install automatic water level controller in their homes was on much higher side. The

\begin{tabular}{|c|c|c|c|}
\hline $\begin{array}{l}\text { SL. } \\
\text { NO }\end{array}$ & $\begin{array}{ll}\text { NAME } & \text { AND } \\
\text { ADDRESS } & \end{array}$ & $\begin{array}{l}\text { WATER } \\
\text { LEVEL } \\
\text { CONTROL } \\
\text { LER } \\
\text { PRESENT } \\
\text { OR NOT } \\
\text { (YES/NO) }\end{array}$ & $\begin{array}{l}\text { WATER } \\
\text { LEVEL } \\
\text { CONTROLL } \\
\text { ER } \\
\text { PREFERRE } \\
\text { D OR NOT. } \\
\text { (YES/NO) }\end{array}$ \\
\hline 01 & $\begin{array}{l}\text { Md. Abdul Razak, } \\
\text { Rose cottage plot } \\
\text { no. 21, Nehru gunj } \\
\text { Bank colony, } \\
\text { Gulbarga. }\end{array}$ & YES & YES \\
\hline 02 & $\begin{array}{lr}\text { Syed } & \text { Samiuddin, } \\
\text { H.no-11-1219 /1E, } \\
\text { Haji } & \text { Yousuf } \\
\text { compound } & \text { M.S.K } \\
\text { mill, Gulbarga. }\end{array}$ & NO & YES \\
\hline 03 & $\begin{array}{lr}\text { Puneet } & \text { Ronad, } \\
\text { H.No } & 3-666 \\
\text { Gazipur, Gulbarga. }\end{array}$ & NO & YES \\
\hline
\end{tabular}
result of the survey is tabulated in table 2 as shown below.

Table 2 survey results for automatic water level controller 


\begin{tabular}{|c|c|c|c|}
\hline 04 & $\begin{array}{lr}\text { Iqbal } & \text { Ahmed } \\
\text { Siddiqui. } & \text { H.No- 7- } \\
\text { 134/2B, } & \text { Gouse } \\
\text { Nagar, } & \text { Tarfile, } \\
\text { Gulbarga. } & \end{array}$ & YES & NO \\
\hline 05 & $\begin{array}{l}\text { Sharanbasava } \\
\text { Hosamani, plot no } \\
14 \text { Jewargi colony } \\
\text { Maka layout, } \\
\text { Gulbarga }\end{array}$ & NO & YES \\
\hline 06 & $\begin{array}{l}\text { Md. } \\
\text { Ahmed, Bait -e- } \\
\text { Ibrahim complex, } \\
\text { Bilalbad colony, } \\
\text { Gulbarga. }\end{array}$ & NO & YES \\
\hline 07 & $\begin{array}{l}\text { Dr. Sayeeduddin } \\
\text { H.No } 6-116 / 2 \mathrm{~A}, \\
\text { Noorani mohella, } \\
\text { ring road Gulbarga }\end{array}$ & YES & NO \\
\hline 08 & $\begin{array}{l}\text { Abdul Hakeem } \\
\text { H.No 5-993/233/A, } \\
\text { near S.B.H bank } \\
\text { Makka colony, Ring } \\
\text { road, Gulbarga }\end{array}$ & NO & YES \\
\hline 09 & $\begin{array}{l}\text { Md. Abdul Muqeem } \\
\text { H.No. 7-990/3A, } \\
\text { near Nehru gunj, } \\
\text { Bank colony } \\
\text { Gulbarga. }\end{array}$ & $\mathrm{NO}$ & YES \\
\hline 10 & $\begin{array}{lr}\text { Masoom } & \text { Ahmed } \\
\text { H.No } & 2-345 / 3 \mathrm{~B}, \\
\text { near } & \text { Nasheman } \\
\text { school, ring road } \\
\text { Gulbarga }\end{array}$ & YES & YES \\
\hline 11 & $\begin{array}{l}\text { Rasool khan H.No } \\
\text { 5-845, Hussaini } \\
\text { Alam, chota roza, } \\
\text { Gulbarga. }\end{array}$ & YES & YES \\
\hline 12 & $\begin{array}{l}\text { Md. Mujeeb H.No. } \\
7-990 / 1 A / 5 \text {, beside } \\
\text { Nawaz burqua } \\
\text { house, Bank colony, } \\
\text { Gulbarga }\end{array}$ & $\mathrm{NO}$ & YES \\
\hline
\end{tabular}

From table 2, we can see that out of the 12 results for automatic water level controller present or not, 5 houses have already installed automatic water level controller prior to our survey and the remaining 7 houses were without automatic water level controller. This is shown in the form of pie-chart in fig.5. We can also observe from table 2 that, out of the 12 results for automatic water level controller preferred or not, 10 houses preferred to install and rest others were not keen to install it. This is shown in the form of pie-chart in fig. 6 .

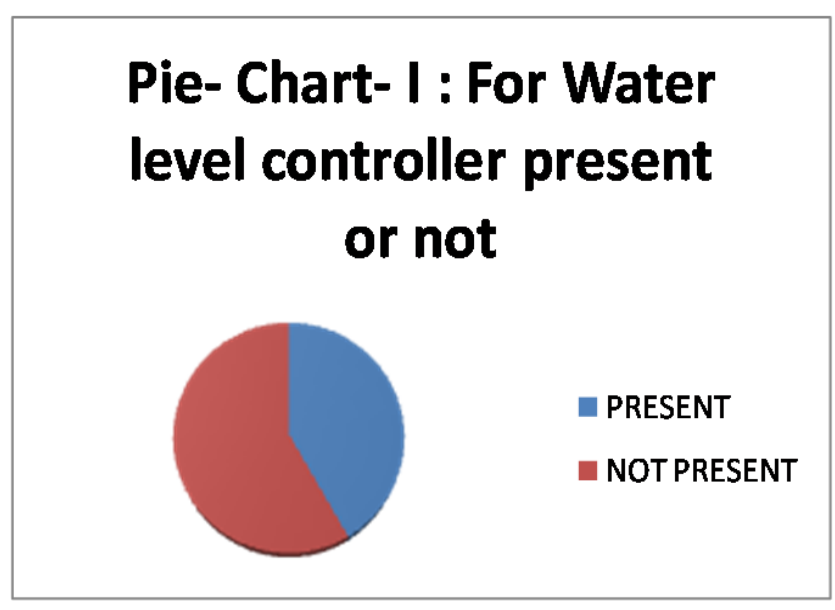

Fig 5 Water level controller present or not

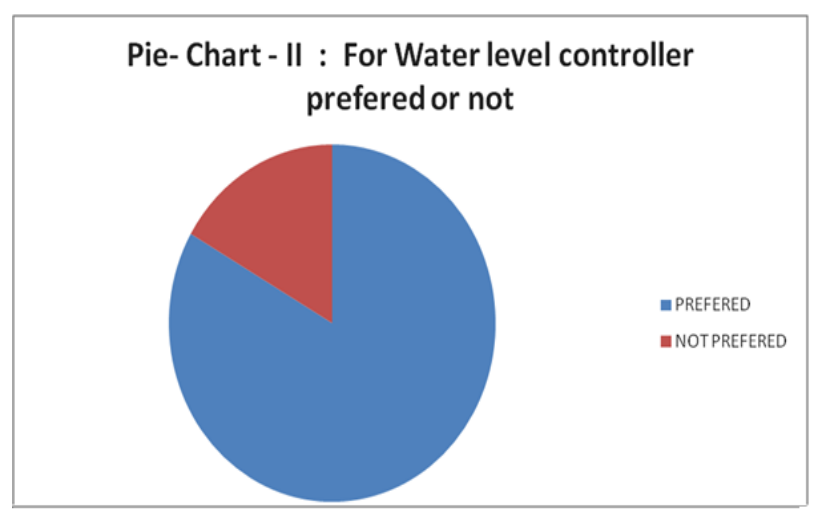

Fig 6 Water level controller preferred or not

\section{SCOPE FOR FUTURE WORK}

Agriculture is India's largest industry and farmlands are spread all over the country. Every crop cannot be cultivated in all places as the soil is not suitable. Even if the soil is suitable due to scarcity of water the land may not be usable. The farmers are mostly dependent on monsoon rain. So the usage of water appropriately is the need of the hour to get the maximum yield. So in this scenario in our proposed system three water level sensors can be used at three different heights from ground level. According to the water requirements by the crops, water can be allowed to the field by the motor. This is one of the aspects that we can improve in our system.

The proposed system can be made more versatile. A number of tailor made variations like control of multiple tanks or multiple pumps are also possible in the future.

\section{CONCLUSIONS}

The automatic water level controller has been successfully designed and developed. The sump pump is turned off and on according to the water levels. Compare to other conventional methods, the automatic water level controller shows excellent 
performance with its reliable digital technology and it is cheaper and durable. The automatic water level controller is a promising controller in terms of system response in water level control with respect to the non linearity introduced by pumps, valves and sensors.

Thus the automatic water level controller is a big boon as concerned with the house hold applications as well as other water saving purposes including agricultural sector and industries. Based on the survey result, it is found that the automatic water level controller has a rising demand and it is a good asset from the electronics perspective.

\section{ACKNOWLEDGEMENTS}

First of all I would like to thank Almighty God by the grace of whom I reached the stage of completion of this work. With a deep sense of gratitude, I express my indebtedness to my reverend guide Prof. Rajendra.R.Patil for his worthy advice, commendable guidance, inspiration and encouragement which were the sources of energy throughout this work. Without his guidance it would have been difficult for me to understand the wide spectrum of information detailing required in this work.

This avenue has been a turning point in my career to mould me into professional. My sincere thanks to the President Poojya Dr. Sharanabaswappa Appa, Dean of administration Dr. Anil Kumar Bidve and Principal Dr. V.D Mytri of my esteemed Institution, Appa Institute of Engineering and Technology

I am also thankful to my father Md. Abdul Razak and my mother Shaheda Begum, who have helped me pave this path to success.

\section{REFERENCES}

[1]. Ning An; Sch. of Mechanical engineering, Hubei polytechnic. University, Wuhan, China; Yu An. "A water level controller for greenhouse sump tank", Mechanic Automation and control Engineering (MACE), 2011 second International conference, Hohhot.

[2]. Chen Hongming; Dept. of Electronics Engineering, Chienkuo technological University, Changhua; Chen Ziyi. "Design of a composite of sliding mode controller applied to water level control for a water tank level system", Control conference, Kunming 2008.

[3]. Hasan, M.R; Department of Electrical and Electronics Engineering, BRAC University, Dhaka Bangladesh; Arifin, K.; Rahman, A; Azad, A. "Design, implementation and Performance of a controller for uninterruptible Solar hot water system". Industrial Engineering and Engineering Management (IE\&EM) 2011 IEEE 18th International conference, Changchun.

[4]. Bhambani, V.; Dept. of Electronics and Computer Engineering, Utah state University, Logan, UT, USA; Yang Quan Chen. "Experimental study of fractional order proportional integral (FOPI) controller for water level control". 47th IEEE conference on Decision and Control, Cancun 2008.

[5]. Joshani, M.; Dept. of Robotics and Autom. Control, University of technology, Malaysia; Yusof, R.; Khalid, M.; Cahyadi, A.I. "Swarm Intelligence based Fuzzy Controller -A Design for Non linear Water Level Tank". Intelligent Systems, Modeling and Simulation (ISMS), 2012 Third International conference Kota Kinabalu.

[6]. Yazdizadeh, A,; Power and water University of Technology, Tehran, Iran; Mehrafrooz, A.; Farahani, K.D.; Barzamini, R. "Adaptive PID Controller design with application to non linear water level in NEKA power plant". Communications, Control and Signal Processing (ISCCSP), 2014, 4th International Symposium, Limas sol.

[7]. Hong-Ming Chen; Chienkuo technological University, Changhua, Zi-Yi Chen; Juhng-Perng Su. "Design of a Sliding Mode Controller for a Water Tank Liquid Level Control System". Innovative Computing, Information and Control, 2007. ICICIC'07, second International conference, Kumamoto.

[8]. Sojoudizadeh, R.; Department of Civil Engineering, Islamic Azad University, Mahabad Iran; Aminifar, S; Daneshwar, M.A; Yosefi, G. "Design of a new intelligent CMOS controller chip for control water level in tanks". Education Technology and Computer (ICETC), 2010 2nd International conference, (volume: 5), Shanghai.

\section{BIOGRAPHIES}

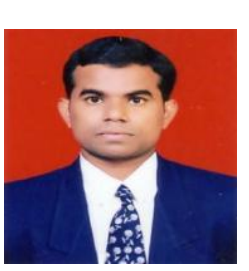

Md. Moyeed Abrar has successfully completed his M-Tech in Digital electronics from Appa Institute of Engineering and Technology, Gulbarga, Karnataka in July 2013. He has completed B.E in Electrical and Electronics from PDA College of Engineering, Gulbarga, affiliated to Visvesvaraya Technological University, Belgaum, Karnataka. His research areas of interests are Control systems, Digital Circuits and logic design, Electrical machine design, Power and Energy systems.

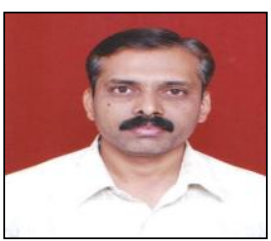

Rajendra R. Patil is working as Asst. Professor in the Dept. of E\&CE of Appa Institute of Engineering and Technology, Gulbarga, Karnataka, since 2007. Earlier he has worked as R\&D Engineer and Asst. Manager in Motwane (P) Ltd Bangalore, a pioneer in Industrial site communication systems. $\mathrm{He}$ has done his B.E (E\&CE) and M.Tech in PDA Engineering College Gulbarga, affiliated to Visvesvaraya Technological University, Belgaum Karnataka. Currently he is pursuing $\mathrm{PhD}$ in Applied Electronics, Gulbarga University Gulbarga. His research areas are antenna, wireless communication, microcontrollers, nonmaterial, and nanotechnology 